\title{
By poles which may Alter Political Landscape of U.P. and Bihar in 2019 Indian General Elections
}

\author{
M.L. Sehgal \\ Fmrly: D.A.V. College, Jalandhar(Punjab), India
}

\begin{abstract}
The present study is an attempt to give an idea of the number of parliamentary constituencies which may change hands between the N.D.A. and the United Opposition if it comes to Modi versus the REST in 2019 Lok Sabha elections. It, now, looks certain, especially when the B.S.P., after forgetting its personal and political animosity, extended its whole hearted support to S.P. in the Gorakhpur and Phulpur Lok Sabha by poles to be followed by the United Opposition (B.S.P., S.P and UPA) in Kairana along with the support of the Peace Party and the other Smaller Parties especially the NISHAD Party in U.P. This resulted in the consolidation of Muslims (19.26\%), Yadavs (14.0\%), Dalits (21.1\%) and Nishads-a politically important O.B.C. class $(5.0 \%)$ in U. P. In Bihar, despite Lalu Prasad's conviction, his son Tejashwi Yadav has come of his age to lead R.J.D and was able to retain Araria parliamentary seat even in the face of stiff opposition from the ruling NDA. These two states, together, have served as a basket full of votes for N.D.A. in 2014 by sending 104 out of the120 Law Makers in India's Lower House of Parliament of 543strength. So both the B. J.P. and the Opposition will have to put their best foot forward-B.J.P for staying in power and Opposition for snatching the power in the coming general elections as the road to attain power in Delhi passes through U.P. and Bihar.
\end{abstract}

Key Words: Gorakhpur, Phulpur, Araria, Kairana, S.P.- B.S.P. Combine, Tejashwi Yadav, Jitan Ram Manji

\section{INTRODUCTION}

After $26^{\text {th }}$ of May, 2014, the day Mr. Narendra Damodardas Mody took over as the $14^{\text {th }}$ Prime Minister of India, the N.D.A. has won assembly elections in10 new states; 8 of which were previously held by UPA and one each by C.P.M. and S.P. [1].In addition, it could retain two [2] but lost one [3] (Bihar regained) out of the three states which were held by N.D.A. before Modi's coronation. Till now N.D.A. was ruling in 20 states [4] of the country- a remarkable achievement for any Indian P.M. Conversely, N.D.A's performance in the 27 Lok Sabha constituencies where the by-elections have held looks minimal as it could not win even one new seat though there were 11 seats which it could have snatched from opposition [5].Out of the 14 Lok Sabha seats won by B.J.P. in 2014, it had lost eight [6] to opposition and could retain only 6 seats [7].Its allies could hold on only to one [8] of the two seats [9] where by poles were held till date.

The bitterly fought Gujarat's assembly election in which the B.J.P. managed to scrap through(18 ${ }^{\text {th }}$ Dec., 2017) with 99 versus 77 seats[10] against the well crafted united quartet of the Patidar, O.B.C. and Dalit leaders: Hardik Patel ,Alpesh Thakor and Jignesh Mevani respectively and Rahul Gandhi - the newly enthroned enthusiastic president of the Congress party with his 'new found love for 'Hinduism', a 'devotee of Lord Shiva' and the 'one who wears the sacred thread' followed by his 25 visits to almost every important Hindu temple of the state[11]. The quartet addressed a vast number of election rallies in whole of the state with no holds and bars for ruling Party. Mr. Modi was shaken badly. The B.J.P., bearing the brunt of 16 
years of incumbency, returned with equal fire by addressing over100 election rallies which were, almost, equally shared between the P.M. and the B.J.P. president. In addition, a large number of rallies were, also, addressed by the local and central BJP ministers including B. J. P's face of Hindutva- Yogi Adityanath to bolster its election campaign. Even the well meaning Arun Jaitley [12], who would rarely address any election rallies, proclaimed:

"B.J P. has always been seen as a pro-Hindutva party. So

if an original is available why one would prefer a clone?"

The urban voters stood with the B.J.P. and it emerged victorious in the Gujarat [13] civic polls (19 th Feb., 2018).

After having ciphered Ms. Mayawati's B.S.P and reducing Akhilesh Yadav's S.P. (Akhilesh replaced his father Mulayam Singh Yadav) to a single digit, i.e. 5( now 7 after two recent wins in U.P by-poles) in the present $16^{\text {th }}$ Lok Sabha [14] who until $15^{\text {th }}$ Lok sabha (2009) would boast of their formidable groups of 23 and 21Lok Sabha members [15] respectively. The B.J.P., led by P.M. Modi, again, reduced both these parties to poor 47 and miserable 19 member parties respectively in 403 member strong U.P. assembly in the November, 2017 elections[16]. But luck failed Modi thereafter. Barely after one year, the B.J.P. was badly defeated in Gorakhpur and Phulpur Lok Sabha by- poles (14 $4^{\text {th }}$ March, 2018); Gorakhpur being a "Yogi's Citadel" as he had represented this constituency for five times and vacated it only a year back to become the C.M. Phulpur seat was also held by the B. J.P's Keshav Prasad Maurya who went on to become Yogi's deputy. With Kairana Lok Sabha and Noorpur Assembly by poll losses (31 ${ }^{\text {st }}$ May, 2018), the humiliation for the B.J.P. was complete.

Still another shock for the N D.A. [B.J.P., J.D. (U.), R.L.S.P., L.JS.P] was in store from Bihar where it was not able to stop R.J.D., now led by Lalu's son Tejashwi Yadav, to retain Araria Lok Sabha and Jejanabad Assembly seats while the BJP was able to retain Bhabua [17] assembly seat (14 ${ }^{\text {th }}$ March, 2018). Araria Lok Sabha seat fell vacant after the death of the R J. D's M.P. and the balloting in Jehanabad and Bhabua assemblies was needed after the deaths of R.J.D. and B.J.P. legislators respectively. On 31 $1^{\text {st }}$ May, 2018, NDA, again, suffered a massive defeat in Jokihat assembly seat at the hands of R.J.D (Table: IV).

The recently concluded Karnataka Assembly elections (14 ${ }^{\text {th }}$ May, 2018) saw B.J.P becoming the largest party. But it fell short of 7 M.L.A s from the absolute majority(111) and lost to it Congress and J.D(S) combine as they, together, had 115 M.L.A s. Congress was content to make the junior partner, the JD(S)'s H.D. Kumara swami as the C.M. to keep B.J.P out of power[18].

\section{METHODOLOGY}

The research material was collected both from the official and non-official agencies using primary and secondary sources. The primary sources are available at Archives of General Elections: Election Commission of India and those of the states. The secondary sources such as the speeches, the twitter accounts of various political leaders, the newspapers and the articles were assessed to present an objective work as far as possible. The expanded forms of the names of political alliances and various political parties are listed in Table: I.

\section{DISCUSSION}

Mr. Omar Abdullah, former C.M. of J\&K., a friend turned political foe of B. J. P remarked [19] about B. J. P's sweeping victory in U.P. Assembly elections (11 ${ }^{\text {th }}$ March, 2017):

"It's 'B.J.P. tsunami' in U.P. and not a ripple in a small pond.

At this rate, we might as well forget 2019 and start planning /

hoping for 2024". He, further, stated "There are no leaders with 
a pan- India acceptability who can take on Modi and no party which can challenge the B.J.P. in 2019".

The ferocity of the Gujarat assembly elections rejuvenated the Congress though it narrowly lost to the ruling B.J.P [10]. The message to the ruling party was loud and clear that 'don't take the voters, especially the rural voters, for granted' as rural peoples had, overwhelmingly, voted for the Congress in the Gujarat state assembly elections.

The events in Indian politics during the last few months have taken a different turn for Mr. Modi especially after the victories of S.P. and B.S.P. combine in Gorakhpur and Phulpur bypoles of U.P. [14] and a status quo in the Araria Lok Sabha seat in Bihar by R.J.D [17]. After winning the two U.P. by-poles, the over- enthusiastic Akhilesh Yadav, former U.P. C.M. wrote [20]:

"If this is the anger of people in areas of C.M. and Deputy C.M., you can imagine the anger of the people of the rest of the country"

A sweeping statement from the Congress president -Rahul Gandhi after these two victories reads as:

"Ruling B.J.P. would suffer the kind of collapse not seen in years and even prime minister Narinder Modi could lose in his constituency Varanasi in Uttar Pradesh in 2019 national elections"[21].

Perhaps he forgot that both the candidates of his Congress party had lost their deposits in the two by poles,

So much so, the re-elected, a well meaning, die hard protagonist of having an alliance with Congress, the C.P.M. general sectary Sita Ram Yechury, whose party suffered an unprecedented drubbing in Tripura [22] with the whole of N.E. of India [23] at the hands of N.D.A. declared that:

\section{"Our main task is to defeat B.J.P"[24].}

Although, losing a few Lok Sabha by- poles out of overwhelming majority should not imply any loss in the faith in the policies of the N.D.A., yet it has started a buzz in the political circles as regards to the future coronation of the N.D.A. The P.M. Modi, who, at one time, was looked upon with respect and awe, now, has become an object of ridicule at the hands of B.S.P., S.P. and R.J.D. not to be lagged behind by the U.P.A. and even by the seven splinter Communist Parties[25] conveniently forgetting that the U.P.A. lost 8 state assemblies[3] ; the 'Red Castle' of Tripura[22] was demolished; S.P. lost power in U.P. and the B.S.P. was reduced to a scratch by Modi's Charisma in these four years (2014-18).

We try to explain the ramifications of these political developments to probe whether this exuberance on the part of opposition parties would remain to be their misplaced outbursts or turn into a reality. No doubt, this can, only, be answered in 2019,i. e. in the coming $17^{\text {th }}$ Lok Sabha elections, but it has, certainly, given a food for thought to the political pundits: Whether 2019 Lok Sabha election will witness Modi versus the REST_or Modi versus MANY? A highly unpredictable political debate follows.

The discussion is divided into parts:

\section{Uttar Pradesh (U.P.)}

U. P. being most populous and, thus is politically most significant state of India as it sends 80 members to the Lok Sabha of India out of its 543 strength. In the present $16^{\text {th }}$ Lok Sabha 
(2014), the N.D.A. had an original total strength of 282 M.P s of B.J.P [26] to make it the first party of having won an absolute majority of its own in the Lower House of the Parliament after 1989[27] .Out of these 282 B.J.P. members, 93 were elected from U.P. (71) and Bihar (22) which, together, send a total of 120 members to the Lower House of India's Parliament.

\section{B. J. P's Tsunami in 2014 Lok Sabha}

The B.J.P. and its alliance partner -A.D., together, won $73(71+2)$ seats; 5 went with S.P. and 2 were annexed by UPA [28] (Congress, R.L.D. and M. D.). B.S.P., R.L.D [29] and M. D. (which hoped that the O.B.C. voters of western U.P.-Shakyas, Mauryas and Kushwahas would support it) were reduced to a naught in 2014 General Elections [30]. The \% vote share of the four combinations consisting of (B.J.P and A.D) S.P., B.S.P. and U.P.A. (Congress, R.L.D. and M. D.) was: $43.2(42.3+1), 22.2,19.6$ and 7.5 respectively [31].

\section{The Tsunami Continues in 2017 Assembly Elections}

In November, 2017 assembly elections, N.D.A. (B.J.P., A. D., S.B.S.P.) remained intact [30]; S.P, Congress and R. L. D., formed a new alliance while B.S.P., again, went in for a lone furlough. These three combinations ended up with winning $325(312+9+4), 56(47+7+1)$ and 19 seats respectively with an average \% vote share of $42.0,22.2+6.2+1.8=30.2$ and 21.9 respectively [32].

\section{S.P.-B.S.P. Combine Trounces BJP in Gorakhpur and Phulpur}

But the equations changed dramatically at the time of by-elections in Gorakhpur and Phulpur (14 ${ }^{\text {th }}$ March, 2018) both of which were won by B.J.P. in 2014. Forgetting their personal and political enmities, the two sworn enemies- Ms. Mayawati (B.S.P.) and Mr.Akhilesh Yadav (S.P.) patched up with each other. With the support of smaller parties, they blighted the B.J.P. in these two Lok Sabha seats with 21881 and 59513 votes [33] of the $47.45 \%$ and $37.39 \%$ polled votes [34] respectively (Table: IIA).

The huge \% vote share of S.P. and B.S.P. combine, even without any understanding with Congress in U.P. (Table: IIA) over N.D.A. should, really, be worrying for the ruling B.J.P. The two major state parties, i.e. S.P. and B.S.P of U.P. could, amply prove that contesting together against the powerful B.J.P., it may be more than possible to trounce the invincible looking Modi. Having Congress and Communists (though less relevant in the U.P.) at their back as hinted by Rahul [21] and Yechury [24], it looks like that the going may be tough for B.J.P. if faced with such a coalition where the S.P., B.S.P., the various Communist parties, R.LD., the smaller parties [35] and Congress may fight the 2019 Lok Sabha elections together. All said, their combination would tantamount to a 'Modi versus the REST'. This makes a formidable vote bank of castes and communities and newly energized Opposition Cadre to make the B.J.P's task of repeating a 2014 in 2019 an uphill task in these circumstances. C.M. Yogi played down his crushing defeats at the hands of Akhilesh and Mayawati as [36]:

"The over-confidence and inability to understand the electoral understanding between the SP and the BSP led to the defeat".

\section{Modi Again Humbled by the United Opposition in Kairana}

As recently as on $31^{\text {st }}$ May, 2018, the ruling BJP suffered a third consecutive defeat in the Kairana Lok Sabha by poll when the United Opposition comprising S.P., B.S.P and UPA (Congress and R.L.D) and many other smaller parties again, humbled Modi's B.J.P. making it a 3-0 clean sweep in U.P. (Table: IIA, B). Mriganka Singh (B.J.P candidate) conceding the defeat in Kairana Lok Sabha by poll said:

"We were not able to communicate to people the work done by BJP" 


\section{Four Scenarios in 2019 for U.P.}

We consider four scenarios while projecting of the expected number of seats in U.P. with the assumption that the opposition index of unity in each one the four scenarios is always equal to $100 \%$ (a tall talk).

(I) Only S.P. and B.S.P. align (II) The three main stake holders namely S.P., B.S.P. and U.P.A. (Congress, R.L.D. and M. D.) align (III) It includes S.P., B.S.P., Congress, R.L.D., M. D., the Seven Communist Parties and an innumerable number of smaller parties[34] excluding P . P. and A. A. P. (IV) Modi versus the REST- which includes all the parties included in (III) along with P. P. and A. A. P. (Table: I).

With 2014 to be base year, the results are summarized in Table: 3 where the expected tallies of seats are shown bold.

(a) If S.P. and B.S.P. had fought the 2014 Lok Sabha elections together, they could have bagged 29 seats which is 24 more than the actual number of seats won by both the parties $(S . P .=5$; B.S.P.=0) (b) If there were an alliance among S.P., B.S.P. and U.P.A.( Congress, R.L.D. and M.D.) in 2014 Lok Sabha elections, they might have ended with a whopping number of 44; a net gain of 37 seats from their previous score in 7 seats (c) If S.P., B.S.P., U.P.A. and Smaller parties[35] excluding P.P., A.A.P., Q.A.D., R.P.D. and S.B.S.P. had combined, their kitty would have swelled to 47 seats (d) Finally, if it were Modi versus the REST in 2014, the combined opposition would have claimed 49 seats as the five aforesaid political parties had won $5 \%$ to $20.5 \%$ of votes in some Parliamentary constituencies of the state (Table: III).

\section{Bihar}

With 40 Lok Sabha seats, Bihar has a unique place as the bulk of its population comprises of lower-caste, lower-class and Muslims. So it needs a sharp intellect and political acumen for the leaders to hold their vote-bank together.

\section{Modi Outclasses Lalu and Nitish}

The R.J.D., headed by Lalu Prasad Yadav, claims itself to be a secular front representing the minority. However, the General Elections in May, 2014 proved that Lalu Yadav did not command the same popularity. This led N.D.A. (B.J.P. ,L.JS.P and R.L.S.P.) to win $31(22+6+3$ ) seats ; the U.P.A. (Congress, N.C.P. and R.J.D.) could win only $7(2+1+4)$ seats while Nitish Kumar of the J.D.(U), who claimed to be the face of a non-communal forces of Bihar and indicated his preference for a Third Front along with other secular parties ended up with just two seats[37]. None of the other parties like the Communists, the J.M.M., the S.P. and the B.S.P. could, even, open their accounts in the $16^{\text {th }}$ Lok Sabha in Bihar. The \% vote share of the three combinations- N.D.A., U.P.A. and J.D. (U) was: $38.80 \quad(29.40+6.40+.3 .00)$, $29.70(8.40+1.20+20.10)$ and 15.80 respectively [38]

\section{Mahagatgbandan (The Grand Alliance) Outwits Modi}

In the Bihar Assembly elections in 2015, where J.D.(U)., R.J.D. and Congress formed the Mahagatgbandan with a front of smaller parties like- S.P., N.C.P., S.S.P., N.P.P., S.J.P., Janadhikar Party [37] ,we saw a reversal with Mahagatgbandan badly mauling the N.D.A.(B.J.P., L.JS.P., R.L.S.P. and H.A.M.-S; a new partner);avenging their 2014 General Election thrashing at the hands of N.D.A. by winning together a total of 178 assembly seats[J.D.(U).=71;R.J.D.=80; Congress $=27$ ].The N.D.A. could win only 58 assembly seats (B.J.P=53, L.JS.P. $=2$ R.L.S.P. $=2$ and H.A.M.-S.=1)[38] out of 243 seat Bihar state assembly strength. 
The N.D.A., this time, had a poor show with a total of $34.1 \%(24.4+4.8+2.6+2.3)$ vote share against the $41.9 \%(16.8+18.4+6.7)$ vote share of the Mahagathbandhan. R.J.D. was the biggest gainer with respect to the number of assembly seats while B.J.P. still enjoyed a 'Cold Comfort' [39] of having led all these parties in \% vote share though there was a net decline of $5.3 \%$ vote share from its 2014 Lok Sabha elections (29.7\%).The difference of $7.8 \%$ of votes (41.9-34.1) translated into a difference of 120 seats between the two alliances. But the J.D. (U) and R.J.D. parted ways in 2017[40] and J.D. (U) had to align with N.D.A. This gave a boost to N.D.A. to make it a very formidable alliance of five parties- B.J.P., L JS.P., R.L.S.P., H.A.M.-S and J.D. (U). Its $\%$ vote share swelled to $54.6(29.40+6.40+3.00+15.8)$ and 2 more MPs in the large NDA flock. At this time, the things looked bright for N.D.A.

\section{Lalu Yadav's Son Tejashwi Yadav Shines}

But Lalu Yadav's young son -Tejashwi Yadav came of his age to attain the role of a mentor of R.J.D in the absence of his father and outfoxed invincible looking N.D.A. to retain Araria Lok Sabha and Jejanabad Assembly seats (14 ${ }^{\text {th }}$ March, 2018). Of course, B.J.P. could retain Bhabua assembly (Table: IV).

\section{Manji: The Aaya Ram- Gaya Ram (Changing Sides Frequently) of Bihar}

This turned out be another big morale booster for the political parties opposed to Mr. Modi. Like U.P., they started thinking of making a Modi versus the REST also in Bihar. The first wicket to fall for N.D.A. was H.A.M.-S., a political outfit formed by unpredictable Mr. Jitan Ram Manji - a veteran politician and a prominent Maha-Dalit leader of Bihar [40] who was earlier elected as a J. D. (U). MLA (2010) from the Makhdoompur assembly constituency of the Jehanabad district and was a minister for S.C. and S.T. in Nitish Kumar government. He was made a stopgap Chief Minister after Nitish Kumar took J.D. (U) debacle in 2014 Lok Sabha elections as his moral responsibility. Mr. Manji remained the $23^{\text {rd }}$ C.M. of Bihar from 20 ${ }^{\text {th }}$ May, 2014 to $22^{\text {nd }}$ February, 2015. When asked to vacate the exalted chair, he rebelled but was made to resign and Nitish Kumar was reinstalled as the C.M. In retaliation, his outfit- H.A.M.-S joined NDA; contested 21 assembly seats but only Mr. Manji, himself, managed to win from Imam gang (though he, also, contested from Makhdoompur). After NDA lost Araria Lok Sabha and Jehanabad Assembly seats at the hands of R.J.D, he, again, changed sides, i.e. deserted N.D.A. for R.J.D.

\section{Tejashwi Yadav Again Torments Modi and Nitish}

Lalu Prasad being in jail, his son Tejashwi Yadav, successfully, led his party- R.J.D and again defeated the ruling N.D.A candidate in Bihar's Jokihat assembly seat which fell vacant after the sitting J.D (U) M.L.A. joined R.J.D following Nitish Kumar's decision to go with BJP. It was more of a battle of prestige for the former allies-R.J.D and J.D. (U.) where R.J.D's defeated the JD (U) by 41391 votes. After a massive victory, Tejashwi said [41]:

"Loss was a lesson for Chief Minister Nitish Kumar who broke away

from the anti-B.J.P. grand alliance and joined hands with B.J.P”.

Presently, the Bihar's political landscape is divided into two blocks- the N.D.A. [B.J.P., L. JS. P., R.L.S.P and J.D. (U)] and the UPA (Congress, N.C.P., R.J.D., H.A.M.-S.). But having retained Araria Lok Sabha and Jehanabad and Jokihat assemblies even in the face of formidable N.D.A. ruling alliance consisting of four political parties at the time of the Jokihat by- election, the UPA, now, seems to be upbeat because Manji's H.A.M.-S has opted out of N.D.A. It is feared that Manjhi's decision may set a trend which other N.D.A constituents may follow before 2019 Lok Sabha election though, till date, its other four constituents have shown their solidarity with N.D.A. Mr. Manji, who belongs to Bihar's electorally significant Mushar community [42] may, further, give a flip to the amalgamation of Dalit politics which, inheritably, are inclined towards Lalu's R.J.D. 


\section{N.D.A. May Still Hold On in Bihar}

Since we are inclined to know about the political landscape of Bihar in 2019 if it were Modi versus the REST, we give $1.1 \%$ advantage to U.P.A. (50\% of H.A.M.-S. vote share in 2015 Assembly elections) by subtracting this \% from the combined \% vote share from present N.D.A. [(B.J.P., L.JS.P., R.L.S.P. and J.D. (U. )] and adding it to \% vote share of the REST( Congress, N.C.P., R.J.D., H.A.M-S., J.M.M., S.P., the seven Communist Parties and B.S.P) taking 2014 as the base year. Of course, it will be a difficult task to quantify exactly Maji's effect on the erosion on the number of votes of N.D.A. which would go in favor of U.P.A. since H.A.M.-S was not in existence in 2014 and Manji was, then, in J. D. (U). The tentative results are given in Table: V.

It looks that even if all the opposition parties unite, they may get more \% vote share than the united N.D.A. only in four seats ( shown bold); of course taking the 2014 to be base year in 2019.

\section{CONCLUSIONS}

(I)After having tasted four successive wins- three in U.P and one in Bihar Lok Sabha by polls, the opposition would be roaring to go in for a bigger onslaught on B.J.P. in 2019 General Elections with some sort of understanding with like -minded parties such as Congress, N.C.P., the seven Communist parties, R.L.D., M.D. and the Smaller parties who consider B.J.P. to be their common political enemy. But there is a word of causation in the U.P. analysis. Although, 2019 will not be a 2014 when Modi's wave at its zenith, yet we should give some \% vote share allowance to a single party- B.J.P. because the index of unity among the two opposing parties (S.P. and B.S.P. - Scenario-I) may not reach 100\%. Again, as the number of opposing parties increases, their index of unity would decrease all the more and BJP deserves even more \% vote allowance in Scenarios-II,III and IV as would need a complete union of quite a number of parties of different hues.

(II) By-poll results in Bihar look to have delivered two important messages to N.D.A:

(a)People of Bihar did not approve of Nitish Kumar's desertion of the Magagathbandan (Grand Alliance) for N.D.A.

(b) Allegations of corruption and thus the convictions notwithstanding, Lalu Yadav's vote bank- M.Y. (Muslims and Yadavs) is, almost, intact. Rather, it has swelled because the present 'Dalit Turmoil [43]' along with H.A.M.-S of Mr. Manji supporting R.J.D. They may cause an 'AntiBJP' atmosphere to forge a stronger combination - M.Y.D. (Muslims, Yadavs and Dalits). Together, they may act as a strong deterrent in the future coronation of both the N.D.A. in Delhi and Nitish Kumar in Bihar.

(III) The poor performance by the B.J.P. in the successive Lok Sabha by- elections in U.P. and Bihar and their marginal victory over Congress in the Gujarat assembly elections show that even a broad understanding among the three parties: B.S.P., Congress and S.P. in U.P. may slash B. J. P's tally of Lok Sabha seats in 2019 to more than $50 \%$ of the seats it won in U.P. in 2014.Of course, by joining N.D.A., Mr. Nitish Kumar has, certainly given Mr. Modi an edge over UPA in Bihar.

All said, in Indian politics where SELF, OPPORTUNISM and CASTS prevail over the PARTY IDEOLOGIES, WELFARE of the PEOPLES and the R EGIONS, would make it a 'game of glorious uncertainties like that of the game of Cricket'. Again, in elections, One plus One does not, always, make TWO because with such a vast number of political parties of varied interests and different ideologies, it may not lead to their amalgamation, i.e. the inter party transfer of votes would be a huge worry for the respective heads of the parties. But the 'lurking fear' of B.J. P' $\mathrm{s}$ 
victory even in 2019 General Elections may serve as a glue to hold the opposition's flock together.

\section{References and Notes}

Haryana, J\&K.,Jharkhand, Uttarakhand, Assam, H.P., Manipur Meghalaya, Tripura and U.P. The fist 8 states were previously ruled by UPA. Tripura was under CPM while S.P was in power in U.P.

Maharashtra, Gujarat.

Punjab; Bihar is now ruled by N.D.A. since J.D. (U.) deserted R.J.D. for N.D.A.

Assam, Arunachal Pradesh, Bihar, Chhattisgarh, Goa, Gujarat, Haryana, H.P., J\&K., Jharkhand, Maharashtra, M.P., Manipur, Meghalaya, Nagaland, Rajasthan, Sikkim, Uttarakhand, U.P and Tripura.

Kandhamal(Odisha), Mandakh(Telngana), Warangal( Telngana), Mainpuri (U.P), Bangaon (W.B), Tamluk (W.B), Coochbehar(W.B), Uluberia (W.B), Mallapouram (Kerala), Amritsar( Punjab), Araria (Bihar).

Alwar and Ajmer ( Rajasthan), Gorakpur , Phulpur and Kairana ( U.P), Gurudaspur ( Punjab), Ratlam (M.P.) and Phandara- Gondia (Maharashtra.

Beed and Palghar (Maharashtra), Lakhimpur (Assam), Shahdol (M.P.), Vadodara (Gujarat).

Tura (Meghalaya) and Nagaland (Nagaland).

Srinagar (J\&K) and Tura (Meghalaya).

Indian Express- 23rd December, 2017.

First Post-14th December, 2017.

Arun Jetley's dig at Rahul Gandhi in 'The Times of India' dated 2nd December, 2017.

India. Com News Desk- 19th February, 2018.

Archive of General Election 2014 by Election Commission of India.

Summary of the 2009 April/ May Lok Sabha election results by Election Commission of India.

Election Commission of India- results for U.P. Assembly Elections were declared on 11 ${ }^{\text {th }}$ March, 2017.

India. Com News Desk 15th March, 2018.

Election Commission of India-results for Karnatka Assembly Elections were declared on 14 ${ }^{\text {th }}$ May, 2018.

Omar Abdullah's twitter account on March 10, 2017.

Akhilesh Yadav's twitter account on March 14, 2018.

Rahul Gandhi 'Addressing an election rally in Bengaluru on $8^{\text {th }}$ April. 2018.

India.com News Desk - March 12, 2018.

Assam, Arunachal Pradesh, Meghalaya, Nagaland, Sikkim and Tripura.

Sita Ram Yechury ‘On being reelected as CPM General Sectary on 22ndApril, 2018.

Communist Party of India (Marxist), Communist Party of India , All India Forward Block, Revolutionary Socialist Party, Communist Party of India (Marxist- Leninist) Liberation, Communist Party of India (Marxist- Leninist) Red Star, Socialist Unity centre of India (Communist)

B,J.P., now, has 272 members in the Lok Sabha as it has lost 8 seats in between 2014-18 : Alwar and Ajmer (Rajasthan), Gorakhpur and Phulpur ( U.P), Gurudaspur ( Punjab) Ratlam (M.P.) , Kairana (U.P.) and BhandaraGondiya (Maharashtra). Two seats are lying vacant

After P.M. Rajiv Gandhi (31 ${ }^{\text {st }}$ October, 1984 to $2^{\text {nd }}$ December, 1989 ),no single political party could secure the absolute majority( 272 seats) in Lok Sabha till May, 2014.

Lok Sabha election result 2014: Party-wise results.

The Indian Express:The eight seats, which the party has decided to leave for R.L.D., include Fatehpur Sikri, Kairana, Baghpat, Bulandshahr, Mathura, Hathras, Bijnore and Amroha.

Congress left three seats for M.D. - Nagina, Etah and Badaun.

2014 Lok Sabha Election Result Analysis for Uttar Pradesh. 
The Indian Express- 11 $1^{\text {th }}$ March, 2017.

Hindustan Times $-15^{\text {th }}$ March, 2018.

The Times of India - 13 $3^{\text {th }}$ March, 2018.

Nirbal Indian Shoshit Hamara Apna Dal (NISHAD), Peace Party(PP) Ambedkar National Congress; Jansewak Party; Samayak Parivartan Party; Shoshit Samaj Dal; Rashtriya Ulama Council; Quami Ekta Dal; Rashtriya Privartan Dal; Rashtriya Samanta Dal; Lokpriya Samaj Party; Moulik Adikar Party; Suheldev Bhartiya Samaj Party; Ambedkar Samaj Party; Bharatia Republican Paksha ; Rashtriya Sarvajan Party; Rashtriya Krantikari Samajwadi Party; Bundelkhand Party ; Peace Party; Trinamool Congress; All India Minority Front; Republican Party of India(Ambedkar) ; Sanyukt Samajwadi Dal; Bahujan Mukti Party and seven Communist Parties( See Reference: 19).

Decan Chronicle- $14^{\text {th }}$ March, 2018.

Bihar General (Lok Sabha) Election Result- 2014.

Bihar Assembly Election Results- 2015.

The Times of India 'Cold Comfort for BJP'-13 th March, 2018.

Hindustan Times 'The Bihar alliance trouble over Tejashwi Yadav corruption charges '- 15th July, 2017.

By ZeeMedia Bureau, 31 $31^{\text {st }}$ May. 2018.

Financial Express'Why Jitan Ram Manjhi of Bihar dumped National Democratic Alliance and joined Grand Alliance?' - 28th February, 2018.

After Supreme Court, on 20th March, 2018, underlined that "law should not result in caste hatred," and ruled out automatic registration of FIR and arrest in complaint under the SC/ST Prevention of Atrocities Act, 1989 No.33. 
Table: I. Alliances and Political Parties

\begin{tabular}{|c|c|c|}
\hline No. & Abbreviation & Full Form \\
\hline 1 & NDA & National Democratic Alliance \\
\hline 2 & BJP & Bhartiya Janta Party \\
\hline 3 & $\mathrm{AD}$ & Apna Dal \\
\hline 4 & $\mathrm{JD}(\mathrm{U})$ & Janta Dal (United) \\
\hline 5 & LJSP & Lok Janshakti Party \\
\hline 6 & RLSP & Rashtriya Lok Samta Party \\
\hline 7 & HAM-S & Hindustani Awam Morcha (Secular) \\
\hline 8 & UPA & United Progressive Alliance \\
\hline 9 & Congress & Congress \\
\hline 10 & RJD & Rashtriya Janta Dal \\
\hline 11 & $\mathrm{MD}$ & Mahan Dal \\
\hline 12 & NCP & Nationalist Congress Party \\
\hline 13 & SP & Samajwadi Party \\
\hline 14 & BSP & Bahujan Samaj Party \\
\hline 15 & NISHAD & Nirbal Indian Shoshit Hamara Apna Dal \\
\hline 16 & JMM & Jharkhand Mukti Morcha \\
\hline $17-23$ & $\begin{array}{l}\text { Various Com } \\
\text { munist Parties }\end{array}$ & $\begin{array}{l}\text { Communist Party of India (Marxist) , Communist Party of India , All India } \\
\text { Forward Block, Revolutionary Socialist Party, Communist Party of India } \\
\text { (Marxist- Leninist) Liberation, Communist Party of India (Marxist- Leninist) } \\
\text { Red Star, Socialist Unity centre of India (Communist) }\end{array}$ \\
\hline 24 & AAP & Aam Adami Party \\
\hline 25 & $\mathrm{PP}$ & Peace Party \\
\hline 26 & QED & Quami Ekta Dal \\
\hline 27 & SBSP & Suheldev Bhartiya Samaj Party \\
\hline 28 & RPD & Rashtriya Privartan Dal \\
\hline $29-32$ & $\begin{array}{l}\text { SSP, NPP, SJP, } \\
\text { Janadhikar Par } \\
\text { ty }\end{array}$ & $\begin{array}{l}\text { Samras Samaj Party; National Peoples Party; Samajwadi Janta Party; Janadhika } \\
\text { r Party ( All Bihar based parties) }\end{array}$ \\
\hline $33-49$ & $\begin{array}{l}\text { U.P. Based Sm } \\
\text { aller Parties }\end{array}$ & $\begin{array}{l}\text { Ambedkar National Congress; Jansewak Party; Samayak Parivartan Party; Shos } \\
\text { hit Samaj Dal; Rashtriya Ulama Councill; Rashtriya Samanta Dal; Lokpriya Sam } \\
\text { aj Party; Moulik Adikar Party; Ambedkar Samaj Party ; Bharatia Republican Pa } \\
\text { ksha ; Rashtriya Sarvajan Party; Rashtriya Krantikari Samajwadi Party; Bund } \\
\text { elkhand Party ; All India Minority Front; Republican Party of India(Ambedkar) } \\
\text {; Sanyukt Samajwadi Dal; Bahujan Mukti Party }\end{array}$ \\
\hline
\end{tabular}

Table: IIA.U.P. Lok Sabha Bye-elections (Modi Vs SP\&BSP Combine) on 14 ${ }^{\text {th }}$ March, 2018

\begin{tabular}{|c|c|c|c|c|}
\hline Constituency & $\begin{array}{l}\text { \%Vote Share of } \\
\text { SP\& BSP in2014 }\end{array}$ & $\begin{array}{l}\text { \%Vote Share of } \\
\text { SP\&BSP combine } \\
\text { in 2018 }\end{array}$ & $\begin{array}{l}\text { \%Vte Share } \\
\text { of NDA in 201 } \\
4\end{array}$ & $\begin{array}{l}\text { \%Vote Share of } \\
\text { NDA in 2018 }\end{array}$ \\
\hline Gorakhpur & SP=22; BSP=17 & $\approx 53.0$ & 52.0 & $\approx 40.0$ \\
\hline Phulpur & SP=20; BSP=17 & $\approx 57.0$ & 52.0 & $\approx 40.0$ \\
\hline
\end{tabular}


Table: IIB.U.P. Lok Sabha Bye-elections (Modi Vs United Opposition) on 31 ${ }^{\text {st }}$ May, 2018

\begin{tabular}{|c|l|l|c|c|}
\hline Constituency & $\begin{array}{l}\text { \%Vote Share of } \\
\text { United Oppositio } \\
\mathrm{n} \text { in2014 }\end{array}$ & $\begin{array}{l}\text { \%Vote Share of } \\
\text { United Opposition } \\
\text { in 2018 }\end{array}$ & $\begin{array}{l}\text { \%Vote Share } \\
\text { of NDA } \\
\text { in 2014 }\end{array}$ & $\begin{array}{c}\text { \%Vote Share of } \\
\text { NDA in 2018 }\end{array}$ \\
\hline Kairana & $\begin{array}{c}\text { SP=29.43; BSP=1 } \\
\begin{array}{c}\text { i.35; UPA=3.38 } \\
\text { Total=47.16 }\end{array}\end{array}$ & 52.0 & 50.6 & 46.0 \\
\hline
\end{tabular}


Table: III. Vote\% (U.P): BJP Vs [I] SP, BSP [II] SP,BSP, UPA[III] II, Small Parties [IV] III,AAP, PP

\begin{tabular}{|c|c|c|c|c|c|c|c|c|c|c|}
\hline No & Constituency & NDA* & S.P & B .S.P & Scenario-I & UPA $^{* *}$ & Scenario-II & Others a & Scenario- III & Scenario-IV \\
\hline 1 & Saharnpur & 39.6 & 4.4 & 19.7 & 24.1 & 34.14 & $58.25(1)$ & 0.27 & $58.52(1)$ & $58.52(1)$ \\
\hline 2 & Kairana & 50.6 & 29.43 & 14.35 & 43.78 & 3.38 & 47.16 & 0.59 & 47.75 & 47.75 \\
\hline 3 & Muzaffarnagar & 58.95 & 14.51 & 22.76 & 37.27 & 1.16 & 38.43 & 0.37 & 38.80 & 38.80 \\
\hline 4 & Bijnor & 46.40 & 27.79 & 21.92 & 49.71 & 2.32 & $52.03(2)$ & PP1.44 & $52.03(2)$ & $53.47(2)$ \\
\hline 5 & Nagina & 39.10 & 29.26 & 26.10 & $55.36(1)$ & 0.49 & $55.85(3)$ & PP 2.27 & $55.85(3)$ & $58.12(3)$ \\
\hline 6 & Moradabad & 42.98 & 35.30 & 14.29 & $49.59(2)$ & 1.76 & $51.35(4)$ & PP 2.29 & $51.35(4)$ & $53.64(4)$ \\
\hline 7 & Rampur & 37.90 & 35.42 & 8.56 & $43.98(3)$ & 15.37 & $59.35(5)$ & 0.47 & $59.82(5)$ & $59.82(5)$ \\
\hline 8 & Sambhal & 34.45 & 32.97 & 23.46 & $56.42(4)$ & 3.35 & $59.77(6)$ & 0.95 & $60.72(6)$ & $60.72(6)$ \\
\hline 9 & Amroha & 48.25 & 33.82 & 14.87 & 48.69 & 0.87 & 49.56 & 0.22 & 49.78 & 49.78 \\
\hline 10 & Meerut & 47.83 & 19.00 & 26.98 & 45.99 & 3.85 & 49.84 & 0.23 & 50.07 & 50.07 \\
\hline 11 & Baghpat & 42.12 & 21.25 & 14.10 & 35.35 & 19.85 & $55.20(7)$ & 0.30 & $55.50(7)$ & $55.50(7)$ \\
\hline 12 & Gaziabad & 54.26 & 7.65 & 12.38 & 20.04 & 13.68 & 33.72 & AAP- 6.38 & 33.72 & 40.10 \\
\hline 13 & G.B. Nagar & 48.60 & 25.89 & 16.06 & 41.95 & 1.03 & 42.98 & 0.37 & 43.35 & 43.35 \\
\hline 14 & Bulandsahar & 59.85 & 18.16 & 12.74 & 30.90 & 5.85 & 36.75 & 0.44 & 37.19 & 37.19 \\
\hline 15 & Aligarh & 48.35 & 21.41 & 21.25 & 42.66 & 5.89 & 48.55 & 0.29 & 48.84 & 48.84 \\
\hline 16 & Hathras & 51.88 & 17.24 & 20.77 & 38.01 & 8.21 & 46.22 & --- & 46.22 & 46.22 \\
\hline 17 & Mathura & 53.22 & 3.40 & 16.08 & 19.48 & 22.59 & 42.07 & 0.46 & 42.53 & 42.53 \\
\hline 18 & Agra & 52.27 & 12.06 & 25.38 & 37.44 & 3.12 & 40.56 & ---- & 40.56 & 40.56 \\
\hline 19 & Fatehpur Sekri & 44.08 & 22.05 & 26.19 & 48.24(5) & 2.50 & $50.74(8)$ & $0 . .57$ & $51.31(8)$ & $51.31(8)$ \\
\hline 20 & Firozabad & 48.45 & 10.78 & 38.11 & 48.89 & 0.67 & 49.56 & 0.36 & 49.82 & 49.82 \\
\hline 21 & Mainpuri & 22.32 & 57.52 & 13.79 & 71.31(6) & --- & 71.31(9) & 0.29 & $71.60(9)$ & $71.60(9)$ \\
\hline 22 & Etah & 52.25 & 30.14 & 15.19 & 45.33 & 1.37 & 46.70 & --- & 46.70 & 46.70 \\
\hline 23 & Badaun & 32.80 & 49.23 & 15.51 & $64.74(7)$ & 0.44 & $65.18(10)$ & -- & $65.18(10)$ & $65.18(10)$ \\
\hline 24 & Aonla & 41.17 & 27.27 & 19.11 & $46.38(8)$ & 9.44 & $55.82(11)$ & 0.27 & $56.09(11)$ & $56.09(11)$ \\
\hline 25 & Bareilly & 50.90 & 27.26 & 10.42 & 37.68 & 8.27 & 45.95 & 0.75 & 46.70 & 46.70 \\
\hline 26 & Pilibhit & 52.58 & 23.06 & 18.87 & 41.93 & 2.80 & 44.73 & 0.26 & 44.99 & 44.99 \\
\hline 27 & Shahjahanpur & 46.44 & 21.48 & 25.61 & 47.09 & 2.39 & 49.48 & PP- 1.26 & 49.48 & 50.74 \\
\hline 28 & Kheri & 37.32 & 17.22 & 14.99 & 32.21 & 27.00 & $59.21(12)$ & 0.30 & $59.21(12)$ & $59.21(12)$ \\
\hline 29 & Daurahra & 33.99 & 22.08 & 22.14 & 44.22(9) & 16.13 & $60.35(13)$ & 1.07 & $61.42(13)$ & $61.42(13)$ \\
\hline 30 & Sitapur & 40.56 & 15.17 & 35.61 & $50.78(10)$ & 2.83 & $53.61(14)$ & 1.03 & $54.64(14)$ & $54.64(14)$ \\
\hline 31 & Hardoi & 37.12 & 28.48 & 28.74 & $57.22(11)$ & 2.38 & $59.6(15)$ & 0.30 & $59.90(15)$ & $59.90(15)$ \\
\hline 32 & Misrikh & 41.31 & 19.54 & 32.57 & $52.11(12)$ & 3.31 & $55.42(16)$ & 0.27 & $55.69(16)$ & $55.69(16)$ \\
\hline 33 & Unnao & 43.35 & 17.44 & 16.73 & 34.17 & 16.47 & $50.64(17)$ & 0.43 & $51.07(17)$ & $51.07(17)$ \\
\hline 34 & Mohanlalganj & 40.72 & 21.68 & 27.71 & $49.39(13)$ & 4.70 & $54.09(18)$ & 0.46 & $54.54(18)$ & $54.54(18)$ \\
\hline 35 & Lucknow & 49.33 & 6.89 & 6.07 & 12.96 & 30.85 & 43.81 & ---- & 43.81 & 43.81 \\
\hline 36 & Rai Bareli & 21.10 & 1.26 & 7.73 & 8.99 & 63.95 & $72.94(19)$ & 1.06 & $74.00(19)$ & $74.00(19)$ \\
\hline 37 & Amethi & 34.48 & --- & 6.62 & 6.62 & 46.86 & $53.48(20)$ & 0.98 & $54.46(20)$ & $54.46(20)$ \\
\hline 38 & Sultanpur & 42.57 & 23.56 & 24.01 & $47.57(14)$ & 4.36 & $51.93(21)$ & --- & $51.93(21)$ & $51.93(21)$ \\
\hline 39 & ADPratapgarh & 42.03 & 13.43 & 23.22 & 36.65 & 15.50 & $52.51(22)$ & 0.75 & $53.26(22)$ & $53.26(22)$ \\
\hline 40 & Farrukhabad & 41.75 & 26.28 & 11.77 & 38.05 & 9.82 & $47.87(23)$ & --- & $47.87(23)$ & $47.87(23)$ \\
\hline 41 & Etawah & 46.79 & 28.39 & 20.52 & 48.81 & 1.43 & 50.24 & 0.36 & 50.60 & 50.60 \\
\hline 42 & Kannauj & 42.12 & 43.90 & 11.47 & $55.37(15)$ & --- & $55.37(24)$ & -.. & $55.37(24)$ & $55.37(24)$ \\
\hline 43 & Kanpur & 56.76 & 3.08 & 6.36 & 9.44 & 30.22 & 39.66 & --- & 39.66 & 39.66 \\
\hline 44 & Akbarpur & 49.49 & 15.11 & 20.95 & 36.06 & 9.95 & 46.01 & --- & 46.01 & 46.01 \\
\hline
\end{tabular}


Sehgal, M. L. (2018). By poles which may Alter Political Landscape of U.P. and Bihar in 2019 Indian General Elections. Advances in Social Sciences Research Journal, 5(6) 406-419.

\begin{tabular}{|c|c|c|c|c|c|c|c|c|c|c|}
\hline 45 & Jalaun & 49.00 & 16.16 & 23.35 & 39.51 & 7.40 & 46.91 & 0.83 & 46.91 & 46.91 \\
\hline 46 & Jhansi & 43.59 & 29.32 & 16.18 & 45.50 & 6.64 & $52.14(25)$ & 0.32 & $52.46(25)$ & $52.46(25)$ \\
\hline 47 & Hamirpur & 46.57 & 19.20 & 18.10 & 37.30 & 8.94 & 46.24 & 1.75 & 47.99 & 47.99 \\
\hline 48 & Banda & 39.83 & 22.09 & 26.35 & $48.44(16)$ & 4.27 & $52.71(26)$ & 1.57 & $52.71(26)$ & $52.71(26)$ \\
\hline 49 & Fatehpur & 45.97 & 17.00 & 28.27 & 45.27 & 4.41 & 49.68 & 0.77 & $50.45(27)$. & $50.45(27)$. \\
\hline 50 & Kaushambi & 36.83 & 32.07 & 22.34 & $54.41(17)$ & 3.54 & $57.94(27)$ & 1.52 & $59.46(28)$ & $59.46(28)$ \\
\hline 51 & Phulpur & 52.00 & 20.00 & 17.00 & 37.00 & 6.00 & 43.00 & 0.28 & 43.28 & 43.28 \\
\hline 52 & Allahabad & 35.45 & 28.45 & 18.31 & $46.76(18)$ & 11.58 & $48.34(28)$ & 1.61 & 48.34(29) & 48.34(29) \\
\hline 53 & Barabanki & 42.49 & 14.90 & 15.64 & 30.54 & 22.67 & $53.21(29)$ & 0.33 & $59.95(30)$ & $59.95(30)$ \\
\hline 54 & Faizabad & 48.04 & 20.42 & 13.87 & 34.29 & 12.79 & 47.08 & 1.76 & 48.84 & 48.84 \\
\hline 55 & AmbedkarNa & 41.47 & 28.09 & 22.49 & $50.58(19)$ & 2.19 & $52.77(30)$ & 1.61 & $54.38(31)$ & $54.38(31)$ \\
\hline 56 & Bahraich & 46.37 & 36.11 & 10.39 & 46.50 & 2.40 & 48.90 & 0.83 & 49.73 & 49.73 \\
\hline 57 & kaisergang & 40.33 & 32,06 & 15.51 & $47.57(20)$ & 6.07 & $53.64(31)$ & 0.77 & $54.41(32)$ & $54.41(32)$ \\
\hline 58 & Shrawasti & 35.75 & 26.87 & 20.14 & 47.01(21) & 2.07 & $49.08(32)$ & PP-10.52 & 49.08(33) & $59.60(33)$ \\
\hline 59. & Gonda & 40.99 & 20.58 & 13.24 & 33.82 & 11.66 & $45.48(33)$ & PP-4.89 & $45.48(34)$ & $50.37(34)$ \\
\hline 60 & Domariganj & 31.76 & 18.57 & 20.75 & $39.32(22)$ & 9.36 & $48.68(34)$ & PP-10.55 & $48.68(35)$ & $59.63(35)$ \\
\hline 61. & .Basti & 33.77 & 30.60 & 26.79 & $57.39(23)$ & 2.61 & $60.00(35)$ & 2.05 & $62.05(36)$ & $62.05(36)$ \\
\hline 62 & S.K. Nagar & 34.89 & 23.83 & 24.89 & $48.72(24)$ & 2.19 & $50.89(36)$ & PP-6.86 & $50.89(37)$ & $57.75(37)$ \\
\hline 63 & Maharajganj & 44.66 & 20.27 & 21.89 & 42.16 & 5.42 & 47.58 & 1.48 & 49.06 & 49.06 \\
\hline 64 & Gorakhpur & 52.00 & 22.00 & 17.00 & 39.00 & 4.00 & 43.00 & 1.54 & 44.54 & 44.54 \\
\hline 65 & Kushi Nagar & 38.92 & 11.70 & 13.98 & 25.68 & 29.93 & $55.61(37)$ & 2.89 & $58.50(38)$ & $58.50(38)$ \\
\hline 66 & Deoria & 51.23 & 15.56 & 23.85 & 39.41 & 3.90 & 43.31 & 1.98 & 45.29 & 45.29 \\
\hline 67 & Bansgaon & 47.62 & 15.23 & 26.03 & 41.26 & 5.78 & 47.04 & 1.46 & 48.50 & 48.50 \\
\hline 68 & Lalganj & 36.42 & 29.32 & 26.30 & $55.62(25)$ & 2.45 & $58.07(38)$ & 3.53 & $61.60(39)$ & $61.60(39)$ \\
\hline 69 & Azamgarh & 28.84 & 35.42 & 27.74 & $63.16(26)$ & 1.87 & $65.03(39)$ & 2.33 & $67.36(40)$ & $67.36(40)$ \\
\hline 70 & Ghosi & 35.79 & 15.56 & 22.10 & 37.57 & 1.83 & 39.40 & 15.72 & 39.40 & $55.12(41)$ \\
\hline 71 & Salempur & 45.52 & 18.53 & 18.55 & 37.08 & 4.86 & 41.94 & 0.88 & 42.82 & 42.82 \\
\hline 72 & Ballia & 38.20 & 23.40 & 15.05 & 38.45 & 1.43 & 39.88 & QED17.4 & 39.88 & $57.28(42)$ \\
\hline 73 & Jaunpur & 36.47 & 17.88 & 21.94 & 39.82 & 4.25 & $44.07(40)$ & 3.35 & $47.42(41)$ & $47.42(43)$ \\
\hline 74 & Machhilishahr & 43.91 & 19.18 & 26.66 & 45.84 & 3.64 & $49.48(41)$ & 2.36 & $51.84(42)$ & $51.84(44)$ \\
\hline 75 & Ghazipur & 31.23 & 27.92 & 24.58 & $52.50(27)$ & 1.92 & $54.42(42)$ & RPD-6.1 & $54.42(43)$ & $54.42(45)$ \\
\hline 76 & Chandauli & 40.29 & 19.86 & 25.04 & $44.90(28)$ & 2.65 & $47.55(43)$ & 1.98 & $49.53(44)$ & 49.53(46) \\
\hline 77 & Varanasi & 56.84 & 4.43 & 5.93 & 10.36 & 7.40 & 17.76 & Aap-20.5 & 17.76 & 38.26 \\
\hline 78 & Bhadohi & 41.68 & 24.34 & 25.05 & 49.39(29) & 2.28 & $51.67(44)$ & 1.63 & $53.30(45)$ & $53.30(47)$ \\
\hline 79 & Mirzapur & 43.19 & 10.77 & 21.53 & 32.30 & 15.11 & 47.41 & 1.99 & $49.40(46)$ & $49.40(48)$ \\
\hline 80 & Roberganj & 42.87 & 15.41 & 21.29 & 36.70 & 9.78 & 46.48 & 4.04 & $52.52(47)$ & $52.52(49)$ \\
\hline
\end{tabular}

Table: IV. Bihar Lok Sabha and Assembly Seats

\begin{tabular}{|l|l|}
\hline Araria (Lok Sabha) & $\begin{array}{l}\text { RJD defeated BJP by71988 votes. In 2014, it defeated BJ } \\
\text { P by146504 votes }\end{array}$ \\
\hline Bhabhua (Assembly) & $\begin{array}{l}\text { BJP defeated RJD by 15490 votes. In 2015, BJP defeated } \\
\text { JD(U) by 7744 votes }\end{array}$ \\
\hline Jehanabad (Assembly) & $\begin{array}{l}\text { RJD defeated JD (U) by35036 votes. In2015, it defeated } \\
\text { RLSP by30231 votes }\end{array}$ \\
\hline Jokihat (Assembly) & $\begin{array}{l}\text { RJD defeated JD (U) by 41391 votes. The same candidate } \\
\text { resigned from J.D(U) to join R.L.D. }\end{array}$ \\
\hline
\end{tabular}


Table: V. Vote\%: NDA Vs The Combined Opposition in Bihar

\begin{tabular}{|c|c|c|c|c|c|c|c|c|c|c|c|}
\hline Constituency & BJP(1) & JDU(2) & RLSP(3) & LJSP(4) & $\underset{\mathbf{a}}{\mathbf{N}}$ & $\underset{b}{\operatorname{Congress}(5)}$ & RJD(6) & JMM/SP(7) & $\operatorname{CPI}(8)^{c}$ & BSP(9) & Rest d \\
\hline Valmikinagar & 32.50 & 10.09 & ---- & ----- & 41.49 & 30.31 & ---- & 3.40 & 1.55 & 1.44 & 37.8 \\
\hline P.Champa & 34.43 & 30.53 & ----- & ----- & 63.86 & ----- & 14.25 & ----- & 2.01 & 1.42 & 18.78 \\
\hline Purvi Champa & 48.61 & 15.61 & ----- & ----- & 63.13 & ----- & 25.29 & $\mathrm{SP}=0.29$ & ----- & 1.28 & 27.96 \\
\hline Sheohar & 46.46 & 9.87 & ----- & ----- & 55.23 & ---- -- & 29.46 & $2.33 \& 5.74$ & 0.35 & 3.30 & 42.28 \\
\hline Sitamarhi & ----- & 10.78 & 45.62 & --.-- & 55.30 & --.--- & 29.20 & $\mathrm{SP}=1.08$ & $-\cdots$ & 0.95 & 32.33 \\
\hline Madhubani & 41.29 & 6.50 & ------ & ----- & 46.69 & ------ & 38.92 & ---- & 0.78 & 1.17 & 41.97 \\
\hline Jhanjarpur & 35.64 & 19.51 & ----- & ------ & 54.05 & ----- & 29.76 & ---- & ------ & 1.51 & 32.37 \\
\hline Supaul & 25.42 & 27.82 & ---- & ----- & 51.14 & 33.90 & ---- & ---- & 1.18 & 2.16 & 38.34 \\
\hline Araria & 26.81 & 22.73 & ---- & --.-- & 48.44 & ----- & 41.82 & $-\cdots$ & 0.54 & 1.82 & 45.28 \\
\hline Kishanganj & 32.19 & 6.01 & ----- & ----- & 37.10 & 53.15 & ----- & ---- & ------ & 1.60 & 55.85 \\
\hline Katihar & 32.16 & 10.24 & ----- & ------ & 41.30 & NCP 43.85 & ----- & 3.42 & 0.98 & 0.29 & 49.63 \\
\hline Purnea & 29.13 & 40.39 & ------ & ----- & 68.42 & 11.99 & ----- & 4.86 & 0.76 & 1.08 & 19.80 \\
\hline Madhepura & 24.34 & 30.14 & ----- & ----- & 53.38 & $----=$ & 35.56 & ----- & ------ & 1.74 & 38.40 \\
\hline Darbhanga & 37.13 & 12.32 & ----- & ----- & 48.35 & ----- & 33.00 & ---- & 1.31 & 1.04 & 36.45 \\
\hline Muzaffarpur & 48.39 & 8.78 & ------ & $---\cdot--$ & 56.07 & 25.45 & ---- & $-\cdots--$ & 0.85 & 0.94 & 28.34 \\
\hline Vaishali & ---- & 15.91 & ------ & 33.48 & 48.29 & ------ & 22.60 & ------ & 0.57 & 2.59 & 26.86 \\
\hline Gopalganj & 52.99 & 11.11 & ------ & ----- & 62.91 & 21.23 & ----- & ---- & 1.38 & 1.85 & 25.56 \\
\hline Saran & 41.14 & 12.40 & ------ & ---- & 52.44 & ----- & 36.39 & ---- & ---- & 1.80 & 39.29 \\
\hline Maharagganj & 37.88 & 17.66 & ------ & ----- & 54.44 & ----- & 33.35 & ----- & ---- & 13.22 & 35.77 \\
\hline Siwan & 42.16 & 8.96 & ------ & ----- & 50.02 & $-\cdots--$ & 29.28 & $-\cdots-$ & 9.16 & 1.65 & 41.19 \\
\hline Hajipur & ----- & 10.59 & ------ & 50.36 & 59.85 & 25.44 & ----- & ----- & ----- & 1.40 & 27.94 \\
\hline Ujiarpur & 36.95 & 13.93 & ---- & ---- & 49.78 & ----- & 29.91 & ----- & 6.18 & 1.77 & 38.96 \\
\hline Samastipur & ----- & 22.60 & ---- & 30.53 & 52.03 & 29.75 & ---- & ---- & 1.09 & 1.45 & 33.39 \\
\hline Begusarai & 39.40 & ----- & ---- & --- -- & 38.30 & ----- & 34.03 & ---- & 17.72 & 0.83 & 53.69 \\
\hline Khagaria & $-\cdots-$ & 24.41 & --- & 34.76 & 59.17 & ---- & 26.34 & ---- & 2.71 & 0.72 & 30.87 \\
\hline Bhagalpur & 36.58 & 13.51 & ---- & ----- & 50.09 & ----- & 37.54 & ---- & 0.59 & 1.15 & 40.38 \\
\hline Banka & 30.22 & $-\cdots-$ & --- & $-\cdots$ & 29.12 & $-\cdots-$ & 31.34 & ---- & 24.26 & 1.16 & $\mathbf{5 7 . 8 7}$ \\
\hline Munger & ---- & 26.21 & $-\cdots$ & 37.94 & 63.05 & $-\cdots$ & 19.67 & ---- & 0.50 & 1.21 & 22.48 \\
\hline Nalanda & ---- & 35.31 & ---- & 34.25 & 68.47 & 13.96 & ---- & ----- & 1.64 & 2.59 & 19.78 \\
\hline Patna Sahib & 55.18 & 10.34 & --- & $-\cdots--$ & 64.42 & 24.99 & ---- & $\mathrm{SP}=1.23$ & ---- & 1.10 & 28.42 \\
\hline Patliputra & 39.38 & 9.97 & ---- & ----- & 48.25 & $-\cdots--$ & 35.15 & ------ & 5.29 & 1.76 & 43.30 \\
\hline Arrah & 43.43 & 8.43 & ---- & ---- & 50.76 & ----- & 28.33 & ------ & 10.97 & 0.85 & 41.25 \\
\hline Buxar & 5.99 & 13.20 & ---- & ---- & 48.09 & ------ & 21.06 & ------ & 1.47 & 20.85 & 44.48 \\
\hline Sasaram & 42.84 & 10.92 & ---- & ---- & 52.66 & 35.43 & ----- & ------ & 0.88 & 3.69 & 41.10 \\
\hline Karakat & ----- & 9.74 & 43.01 & $-\cdots--$ & 51.65 & ----- & 29.66 & ------ & 4.15 & 5.78 & 40.69 \\
\hline Jahanabad & $-\cdots$ & 12.46 & 39.86 & $-\cdots$ & 51.22 & ------ & 34.63 & ----- & 4.25 & 1.31 & 41.21 \\
\hline Arungabad & 39.16 & 17.31 & --- & ---- & 55.37 & 30.73 & $-\cdots$ & ----- & --.-- & 3.54 & 35.37 \\
\hline Gaya JRM & 40.29 & 16.28 & ---- & ---- & 55.47 & $-\cdots$ & 26.03 & 4.55 & 0.94 & 1.98 & 34.60 \\
\hline Nawada & 44.12 & 19.02 & ---- & ----- & 62.04 & ----- & 28.28 & ----- & ------ & 0.90 & 30.28 \\
\hline Jamui & ----- & 25.40 & ---- & 36.50 & 60.80 & ----- & 25.53 & 1.37 & 0.80 & 1.92 & 30.72 \\
\hline
\end{tabular}

$\mathbf{a}=$ Sum of \% votes of Parties: 1 to 4 minus HAM-S; $b=$ Congress \& NCP; $\mathbf{c}$-See Reference 25; $\mathbf{d}=$ Sum of \% votes of Parties:5 to 9+ HAM-S 